\title{
Ameliorative effect of epigallocatechin gallate on sodium fluoride induced oxidative stress mediated metabolism in rat
}

\author{
S. Thangapandiyan ${ }^{1}$, S. Miltonprabu ${ }^{2 *}$ \\ ${ }^{1}$ Department of Zoology Annamalai University Annamalainagar-608002 Tamilnadu, India \\ ${ }^{2}$ Assistant Professor Department of Zoology Faculty of Science, Annamalai University Annamalai Nagar - 608002 Tamil Nadu, India \\ *Corresponding author E-mail: smprabu73@gmail.com
}

\begin{abstract}
Background: The present study was designed to examine the ant hyperglycemic and antihyperlipidemic effect of Epigallocatechin gallate (EGCG) on fluoride induced oxidative changes in the metabolisms of rats.

Methods: The control group received the vehicles only. EGCG alone treated group received the EGCG orally at a dose of $40 \mathrm{mg} / \mathrm{kg}$ in $10 \%$ tween 80 for 4 weeks. The Fl treated group received $\mathrm{NaF}(25 \mathrm{mg} / \mathrm{kg})$ orally in saline for 4weeks. EGCG + Fl treated group received the EGCG at a dose of $40 \mathrm{mg} / \mathrm{kg} / \mathrm{bw}$ along with $\mathrm{NaF}$.

Results: The levels of serum SGOT, SGPT, ALP, ACP and plasma glucose, G6PD, cholesterol, triglycerides, free fatty acids, phospholipids, low density lipoprotein, very low density lipoprotein were significantly increased in fluoride intoxicated rats. Furthermore, a significant increase HMG CoA with decreased glycogen, hexokinase, total protein, albumins, high density lipoprotein, lipoprotein lipase, and lecithin cholesterol acyl transferase was observed in fluoride treated rats with altered histological changes. Pre-oral administration of EGCG at a dose of $40 \mathrm{mg} / \mathrm{kg}$ bw to fluoride intoxicated rats for a period of 28 days resulted in a significant reduction in the cholesterol, triglycerides, free fatty acids, phospholipids, low density lipoprotein, very low density lipoprotein, and elevation of high density lipoprotein with hexokinase. Moreover, lipoprotein lipase, lecithin cholesterol acyl transferase, total protein, and albumins were also increased with decreased serum markers and HMG CoA after EGCG treatment. The histological findings of liver also significantly improved with EGCG pretreatment.

Conclusions: These results indicate that the natural dietary antioxidant EGCG showed significant protective effect against Fl- induced oxidative stress mediated metabolic alternations in rats. This may be due to its antihyperlipidemic and ant hyperglycemic property; it will provide an accessible and cheap traditional medicine source for treatment of Fl mediated environmental and occupational ailments.
\end{abstract}

Keywords: EGCG, Fluoride, Metabolisms, Lipids, Anti-Hyperlipidemia ROS, Rat.

\section{Introduction}

Fluorosis is the phenomenon caused by excessive ingestion of fluoride for a prolonged period of time. Intrinsic geological resources and more recently the arrival of increased industrialization and attendant ecological contaminated waste have contributed seriously to the increasing incidence of fluoride-related human health problem. High stratum of fluoride in drinking water has become a future health hazard all over the world, approximately with 66.62 million victims in India alone. Fluoride enters the human and animal body through drinking water and to a slight extent through food (Susheela 2007). High quantity of fluoride ingestion causes metabolic anarchism, by interacting with a variety of cellular processes such as gene expression, cell cycle, proliferation and migration, respiration, metabolism, ion transport, secretion, endocytosis, apoptosis, necrosis and oxidative stress, and disrupts the antioxidant security system in the body (Strunecka et al. 2007; Barbier et al. 2010). Numerous studies have shown that fluorosis may induce nucleotide damage, inhibition of protein synthesis and alters mitochondrial functions resulting in the energy deficient state of the cell (Jeng et al. 1998). Fluoride has already been reported to be hyperglycemic, hyperlipidemics, in fasting blood glucose levels in laboratory animals, which was attributed to lower
Insulin levels (Rupal et al. 2010; Gracia-Montalvo et al. 2009). Philips and Hart (1935) first demonstrated that lipid metabolism was altered by toxic levels of fluoride given to rats. Fluoride exposure is resulting in generation of superoxide anion $\left(\mathrm{O}^{-}\right)$, and its downstream consequences such as hydrogen peroxide, peroxynitrite and hydroxyl radicals, which are important in mediating the toxic effects of fluoride (Barbier et al. 2010). Oxidative stress mediated free radical generation is known to be one of the most important mechanisms of fluoride toxicity (Nabavi et al. 2012). Fluoride has the ability to initiate respiratory burst and stimulate the generation of free radicals, which change the structure and permeability of cell membranes and impair the cell function (Chlubek 2003). Numerous studies have indicated an increased oxidative stress in the serum, liver and brain of animals exposed to fluoride (Grucka-Mamczar et al. 2009). Moreover, fluoride affects the activity of enzymes constituting the cell antioxidant system whose role is to protect against free radicals (Chinnoy 2003).

Recently, the search for appropriate hypoglycemic and hypolipidemic agents has been focused on plants based traditional medicines because, natural products that may be better treatments than currently used drugs (Rates 2001). Therefore, numerous studies have been carried out to evaluate natural products, including plant materials, as alternative treatments for oxidative stress induced diseases. Plants are rich sources of hypoglycemic, 
hypolipidemic and antioxidant agents such as flavonoids, ellagic acids, phenolic acids, phytosterols, gallotannins, and other related polyphenols (Muruganandan et al. 2005). Tea is the second most commonly drank liquid on earth after water. Tea is an infusion of the leaves of the Camellia sinensis plant. Epigallocatechin gallate (EGCG) (Fig.1), the major bioactive constituent of C.sinensis has been reported to exhibit many pharmacological effects, including anti-cancer, anti-hyperlipedemic and anti-hyperglycemic activities against a broad spectrum of research [Li et al. 2006; Singh et al. 2011]. EGCG has been reported to possess strong antioxidant properties (Zhong \& Shahidi 2011). Oral administration of EGCG is capable of protecting several organs such as liver, kidney, testes, heart and brain against oxidative stress induced by free radicals (Thangapandiyan \& Miltonprabu 2013; Thangapandiyan \& Miltonprabu 2014; May Al-Maghrebi et al. 2012; Devika \& Stanely Mainzen Prince 2008; Puneet K \& Anil 2008). However, the role of EGCG against fluoride altered carbohydrates, protein, lipid profiles and lipid enzymes in rats have not so far been studied. Therefore, the present study was carried out to investigate the metabolic alterations in the carbohydrate, protein, lipid profiles and lipid enzymes on fluoride induced oxidative stress mediated metabolism in rats.

\section{Materials and methods}

\subsection{Chemicals}

Sodium fluoride (NaF), Epigllaocatechin gallate (EGCG), 1, 1', 3, 3'- tetramethoxy propane, bovine serum albumin was purchased from Sigma Chemical Co., St. Louis, MO, USA. All other chemicals and solvents were of certified analytical grade and purchased from S.D. Fine Chemicals, Mumbai or Himedia Laboratories Pvt. Ltd., Mumbai, India. Reagent kits were obtained from span Diagnostics, Mumbai, India. Fig.1 Chemical structure of EGCG.

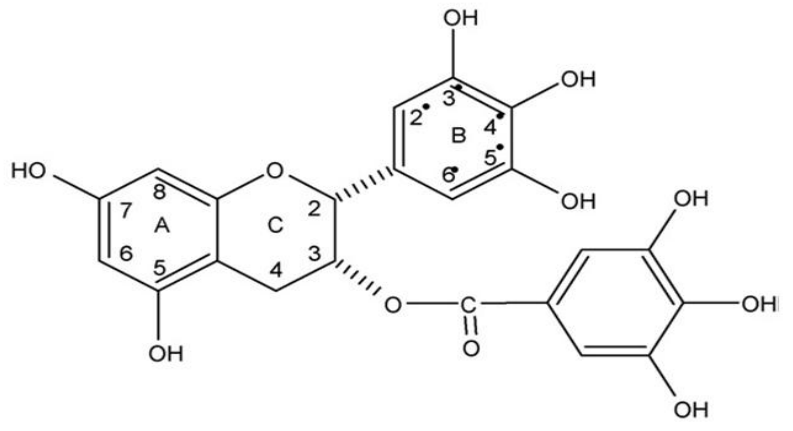

Fig. 1: Chemical Structure of EGCG

\subsection{Animals and diet}

Healthy adult male albino rats of Wistar strain, bred and reared in Central Animal House, Department of Experimental Medicine, Rajah Muthiah Medical College, and Annamalai University were used for the experiment. Males were preferred to avoid complications of the estrous cycle. Animals of equal weight (160-180 g) were selected and housed in polypropylene cages lined with husk and kept in a semi natural light/dark condition (12 h light/12 h dark). The animals had free access to water and were supplied with standard pellet diet ( Pranav Agro Industries Ltd., Bangalore, India), constitution of protein $(22.21 \%)$, fat (3.32\%), fiber $(3.11 \%)$, balanced with carbohydrates $(>67 \%)$, vitamins and minerals. Animal handling and experimental procedures were approved by the Institutional Animal Ethics Committee, Annamalai University (Registration Number: 952/2012/CPCSEA) and the animals were cared in accordance with the "Guide for the care and use of laboratory animals" and "Committee for the purpose of control and supervision on experimental animals".

\subsection{Experimental design}

In the present study, fluoride ( $\mathrm{Fl}$ ) was administered orally (gastric intubation) as sodium fluoride (NaF) at a dose of $25 \mathrm{mg} / \mathrm{kg}$ body weight/day for 4 weeks, which was $1 / 10$ of the oral $\mathrm{LD}_{50}$ value in rats (Chinnoy 1991). Control (Group 1) received the vehicles only, experimental rats were subdivided into two groups (3 and 4). Drug control group (Group 2) received the EGCG $(40 \mathrm{mg} / \mathrm{kg} \mathrm{bw})$ alone. In the experiment, a total of 24 rats were used. The rats were randomly divided into 4 groups of 6 animals in each.

Group 1: $(n=6)$ Control rats received the normal saline and vehicle.

Group 2: $(n=6)$ Rats administered with EGCG $(40 \mathrm{mg} / \mathrm{kg}$. b.w/day) dissolved in Tween 80

Group 3: $(n=6)$ Rats administered with $\mathrm{NaF}(25 \mathrm{mg} / \mathrm{kg} \mathrm{BW})$ dissolved in normal saline

Group 4: $(n=6)$ Rats exposed $\mathrm{NaF}$ and pre-administered with EGCG (40 mg/kg. b.w/day) (Thangapandiyan \& Miltonprabu 2013).

At the end of the experimental period, rats were fasted overnight and anesthetized with pentobarbital sodium $(35 \mathrm{mg} / \mathrm{kg}$, IP) and euthanized by cervical decapitation. Blood samples were drawn from the caudal vena cava, and collected in test tubes and centrifuged at $1500 \mathrm{xg}$ for $10 \mathrm{~min}$ to obtain the serum. Tissue (liver) were dissected out, washed in ice-cold saline and stored at $-20{ }^{\circ} \mathrm{C}$ until used. The tissues were weighed and $10 \%$ tissue homogenate was prepared with $0.025 \mathrm{M}$ Tris- $\mathrm{HCl}$ buffer, $\mathrm{pH}$ 7.5. After centrifugation at $2000 \mathrm{rpm}$ for $10 \mathrm{~min}$, the clear supernatant was used for biochemical assays.

\section{Biochemical assays}

\subsection{Estimation of serum marker enzymes SGOT, SGPT, ACP, and ALP}

Serum glutamate oxaloacetate (SGOT) and pyruvate (SGPT) transaminases, and alkaline phosphatases (ACP, ALP) levels were determined using standard kits (Eve's Inn Diagnostics, Baroda, India).

\subsection{Estimation of plasma glucose, liver glycogen, hexokinase and G6PD activities}

Plasma glucose levels were measured by standard kit (Eve's Inn Diagnostics, India). Hepatic glycogen was extracted with $30 \%$ $\mathrm{KOH}$, and the yield was estimated by anthrone -sulphuric acid method of Seifter et al. (1950). Hepatic hexokinase (EC 2.7.1.1) was determined based on reduction of nicotinamide adenine dinucleotide through a coupled reaction with glucose-6-phosphate dehydrogenase (Brandstup et al. 1957). Glucose-6-phosphatase (EC 3.1.3.9) activity was assayed by measuring the inorganic phosphate liberated from glucose- 6-phosphate (G-6-P) (Baginsky et al. 1974).

\subsection{Estimation of serum protein markers}

The concentration of total protein in the serum was assayed by the method of Lowry et al. (1951) and albumin concentrations were assayed according to the method of Doumas et al. (1971).

\subsection{Estimation of plasma lipid profile}

Plasma total cholesterol, triglycerides, HDL-cholesterol and LDLcholesterol were determined using Diagnostic Kit-Beacon Diagnostics, Kabilpore, Navsari, India. The high density lipoprotein cholesterol (HDL-C) content in plasma was estimated by using a reagent kit (Qualigens Diagnostics, Mumbai, India). Very low density lipoprotein cholesterol (VLDL-C) and low density lipoprotein cholesterol (LDL-C) fractions were calculated as VLDL-C $=\mathrm{TG} / 5$ and LDL-C $=$ total cholesterol $-($ HDL-C + VLDL-C $)$, respectively. 


\subsection{Estimation of lipid marker enzymes}

The activity of HMG-CoA reductase in the liver was assayed by the method of Philipp and Shapiro (1970). In brief, equal volumes of fresh $10 \%$ tissue homogenate and diluted perchloric acid were mixed, kept for $5 \mathrm{~min}$ and centrifuged at $2000 \mathrm{x} \mathrm{g}$ for $10 \mathrm{~min}$.To1.0ml of filtrate, $0.5 \mathrm{ml}$ of freshly prepared hydroxylamine reagent (alkaline hydroxylamine in the case of HMG-CoA) was added, mixed and after $5 \mathrm{~min}, 1.5 \mathrm{ml}$ of ferric chloride was added and shaken well. Reading's weretakenafter10min at 540nm against a similarly treated saline-arsenate blank. The ratio of HMGCoA to mevalonate was calculated. Lower ratio indicates higher enzyme activity and higher ratio indicate slower enzyme activity.

Plasma lipoprotein lipase activity was assayed by the method of Korn (1955). The incubation mixture contained $0.3 \mathrm{ml}$ of ammonium chloride $(0.025 \mathrm{M})$-ammonia buffer $(0.25 \mathrm{M}, \mathrm{pH} 8.5), 0.1 \mathrm{ml}$ of calcium chloride $(1 \mathrm{M})$, and $0.4 \mathrm{ml}$ of substrate and $0.2 \mathrm{ml}$ of plasma. The contents were incubated at $37{ }^{\circ} \mathrm{C}$ for $60 \mathrm{~min}$. At the end of the incubation period, $1.0 \mathrm{ml}$ of cold $0.2 \mathrm{~N} \mathrm{H} 2 \mathrm{SO} 4$ was added to arrest the reaction. In case of control, plasma was added after the addition of $1.0 \mathrm{ml}$ of $0.2 \mathrm{NH} 2 \mathrm{SO} 4$. The liberated glycerol was estimated in analiquot of the incubation mixture.

Plasma lecithin cholesterol acyl transferase activity was assayed by the method of Hitz et al. (1983). $0.6 \mathrm{ml}$ of the substrate was mixed with $0.6 \mathrm{ml}$ of the enzyme. $0.2 \mathrm{ml}$ of this mixture was mixed with $1.0 \mathrm{ml}$ of isopropanol while the remaining mixture was incubated at $27^{\circ} 1 \mathrm{C}$ for $90 \mathrm{~min}$. The precipitate was removed by centrifugation and the supernatant was taken for the estimation of free cholesterol (Zlatkis et al. 1953). This represented the amount of free cholesterol present in the test sample at zero time. After $90 \mathrm{~min}, 0.2 \mathrm{ml}$ of the incubated mixture was mixed with $1.0 \mathrm{ml}$ of isopropanol and the remaining mixture was incubated at $27^{\circ} 1 \mathrm{C}$ for a further period of $90 \mathrm{~min}$. At the end of $180 \mathrm{~min}, 0.2 \mathrm{ml}$ of the incubated mixture was treated with $1.0 \mathrm{ml}$ of isopropanol to arrest the reaction. The precipitated protein in all the tubes were separated by centrifugation and the free cholesterol content in the supernatant were estimated by Zlatkis et al. (1953). Control tubes containing only the substrate were treated similarly to check for complete in activation of plasma during substrate preparations. Lecithin cholesterol acyl transferase activity was expressed as a function of the disappearance of free cholesterol during the incubation period.

\subsection{Estimation of cholesterol}

Lipids were extracted from tissues by the method of Folch et al. (1957) using chloroform-methanol mixture $(\mathrm{CHCl} 3: \mathrm{MeOH})(2: 1$, $\mathrm{v} / \mathrm{v})$. The total cholesterol was estimated by the method of Zlatkis et al. (1953). To $0.1 \mathrm{ml}$ of the lipid extract/serum, $9.9 \mathrm{ml}$ of ferric chloride-acetic acid reagent was added and allowed to stand for $15 \mathrm{~min}$ and then centrifuged. To $5 \mathrm{ml}$ of the supernatant, add $3 \mathrm{ml}$ of conc. H2SO4. The colour developed was read after $20 \mathrm{~min}$ at $560 \mathrm{~nm}$ against a reagent blank. A set of standards (cholesterol $200 \mathrm{mg} / \mathrm{dl}$ ) was also performed in the similar manner. Values were expressed as $\mathrm{mg} / 100 \mathrm{~g}$ tissue and $\mathrm{mg} / \mathrm{dl}$ serum.

\subsection{Determination of triglycerides}

Triglycerides were estimated by the method of Fossati and Lorenzo (1982). To an aliquot of plasma/lipid extract, evaporated to dryness. Volumes of $0.1 \mathrm{ml}$ of methanol, $4 \mathrm{ml}$ of isopropanol were added. To this mixture $0.4 \mathrm{~g}$ of alumina were added and shaken well for $15 \mathrm{~min}$. Centrifuged and then $2 \mathrm{ml}$ of the supernatant was taken for estimation. The tubes were placed in a water bath at 65 ${ }^{\circ} \mathrm{C}$ for $15 \mathrm{~min}$ for saponification after adding $0.6 \mathrm{ml}$ of the saponification reagent $(5 \mathrm{~g}$ of potassium hydroxide was dissolved in 60 $\mathrm{ml}$ of distilled water and $40 \mathrm{ml}$ of isopropanol was added to it) followed by $0.5 \mathrm{ml}$ of acetyl acetone reagent $(0.75 \mathrm{ml}$ of acetyl acetone was dissolved in $60 \mathrm{ml}$ of distilled water and $40 \mathrm{ml}$ of isopropanol was added to it). After mixing, the tubes were kept in a water bath at $65{ }^{\circ} \mathrm{C}$ for $1 \mathrm{~h}$, the contents were cooled. A series of standards of concentrations 8-40 lg triolein ( $1 \mathrm{~g}$ of triolein was dissolved in $100 \mathrm{ml}$ of isopropanol) were treated similarly along with a blank containing only the reagents and absorbance was read at $420 \mathrm{~nm}$. The triglyceride content was expressed as $\mathrm{mg} / 100 \mathrm{~g}$ tissue and $\mathrm{mg} / \mathrm{dl}$ serum.

\subsection{Determination of phospholipids}

Phospholipids content was determined by the method of Zilversmit and Davis (1950). To $0.1 \mathrm{ml}$ of plasma/lipid extract, added $1 \mathrm{ml}$ of $5 \mathrm{~N} \mathrm{H} 2 \mathrm{SO} 4$ and $1 \mathrm{ml}$ of concentrated nitric acid and digested to a colorless solution. The phosphorus content in the extract was determined by the method of Fiske and Subbarow (1925). The values were expressed as $\mathrm{g} / 100 \mathrm{~g}$ tissue and $\mathrm{mg} / \mathrm{dl}$ serum.

\subsection{Determination of free fatty acids}

Free fatty acids were estimated by the method of Falholt et al. (1973). $0.1 \mathrm{ml}$ of plasma/lipid extract was evaporated to dryness. 1 $\mathrm{ml}$ of phosphate buffer, $6 \mathrm{ml}$ of extraction solvent and $2.5 \mathrm{ml}$ of copper reagent $(10 \mathrm{ml}$ of copper solution was mixed with $10 \mathrm{ml}$ of triethanolamine and $6 \mathrm{ml}$ of sodium hydroxide and diluted to 100 $\mathrm{ml}$, then $33 \mathrm{~g}$ of sodium chloride was added and the $\mathrm{pH}$ was adjusted to 8.1) were added. All the tubes were shaken vigorously. $200 \mathrm{mg}$ of activated silicic acid was added and left aside for 30 min. The tubes were centrifuged and $3 \mathrm{ml}$ of the copper layer was transferred to another tube containing $0.5 \mathrm{ml}$ of diphenyl carbazide (1.5 $\mathrm{M}$ in ethanol) and mixed carefully. A solution containing 2 $\mathrm{mg} / \mathrm{ml}$ of palmitic acid in chloroform was used as the standard. The absorbance was read at $550 \mathrm{~nm}$ immediately. The amount of free fatty acids was expressed as $\mathrm{mg} / 100 \mathrm{~g}$ tissue and $\mathrm{mg} / \mathrm{dl} \mathrm{se}-$ rum.

\subsection{Estimation of faecal cholesterol and bile acid con- tent}

The faecal cholesterol and bile acids were extracted using alkaline-methanol medium, and cholesterol was estimated by Kaiek et al. (1984). A portion of the extract was acidified and used for bile acid estimation by the method of Snell and Snell (1953).

\subsection{Histological examination}

A portion of the liver from control and experimental rats were taken and fixed in 10\% buffered neutral formal saline and dehydrated by passing successfully in different mixtures of ethylalcohol-water,cleanedinxylene and embedded in paraffin. Sections of the tissue (5-6 mm thick) were prepared by using a rotary microtome and stained with haematoxylin and eosin (H\&E) dye, which was mounted in a neutral deparaffinated xylene. The structural changes in the sections were examined under a light microscope.

\subsection{Statistical analysis}

Data are presented as the mean \pm SD and were statistically analyzed by one-way analysis of variance (ANOVA) using SPSS version 16.0 (SPSS Inc., Cary, North Carolina, USA) and the individual comparisons were obtained by Duncan's multiple range test. Values for $\mathrm{P}<0.05$ were considered statistically significant.

\section{Results}

\subsection{Effect of EGCG on serum SGOT, SGPT, ACP, and ALP}

The Fluoride administration caused abnormal liver function, in rats. Hence, the activities of serum liver marker enzymes such as 
SGOT, SGPT, ALP and ACP were significantly $(\mathrm{P}<0.05)$ increased when compared with control rats. Whereas EGCG $(40 \mathrm{mg} / \mathrm{kg}$ bw) pre-oral supplemented rats significantly $(\mathrm{P}<0.05)$ decreased the activities of serum hepatic markers. However, oral administration of EGCG alone to normal rates did not show any significant $(\mathrm{P}<0.05)$ effect on serum hepatic markers (Table 1).

\subsection{Effect of EGCG on plasma glucose, liver glycogen, hexokinase and G6PD activities}

Table 2 shows the levels of plasma glucose, liver glycogen, hexokinase and G6PD in control and experimental rats. Fluoride administrated rats significantly increased $(\mathrm{P}<0.05)$ the levels of plasma glucose and hepatic G6PD and decreased hepatic glycogen and hexokinase activity when compared with control. EGCG supplementation resulted in a significant $(\mathrm{P}<0.05)$ decrease in the plasma glucose and hepatic G6PD levels with significant $(\mathrm{P}<0.05)$ increase in the hepatic glycogen content and hexokinase activity in fluoride treated rats. Normal rats treated with EGCG also showed a significant $(\mathrm{P}<0.05)$ difference in the lipids profiles as compared with control group.

\subsection{Effect of EGCG on serum total proteins and albu- min}

Results about the effect of fluoride and EGCG on serum total proteins and albumin are shown in Fig. 2. Fluoride administration at a dose of $25 \mathrm{mg} / \mathrm{kg}$ for 4 weeks evoked a significant decreases $(\mathrm{P}<0.05)$ in total protein as evidenced by decrease in hepatic serum albumin level compared to the control group. EGCG preadministration of fluoride-intoxicated rats enhanced the mitigated total proteins as evidenced by significant $(\mathrm{P}<0.05)$ increase in serum albumin level. EGCG-treated group did not show any significant change compared to the control group.

\subsection{Effect of EGCG on plasma lipid profile}

Table 3 shows the effect of treatment with the EGCG on fluoride induced plasma cholesterol, triglycerides, phospholipids, free fatty acids and lipoproteins in the control and experimental group of rats. The levels of serum cholesterol, triglycerides, phospholipids, free fatty acids, LDL-cholesterol (LDL-C) and VLDL-cholesterol $($ VLDL-C) were significantly $(\mathrm{P}<0.05)$ increased, whereas levels of HDL-cholesterol (HDL-C) significantly decreased in fluoride intoxicated rats when compared with control rats. Pre-oral administration of EGCG to fluoride intoxicated rats significantly $(\mathrm{P}<0.05)$ reversed all these changes into normal levels. Normal rats treated with EGCG alone showed no significant difference in the lipid profiles.

\subsection{Effect of EGCG on plasma lipid marker enzymes}

Figure 3 exemplify the changes in the activities of lipoprotein lipase and lecithin cholesterol acyl transferase in the control and experimental rats. A significant decrease $(\mathrm{P}<0.05)$ in the activities of lipoprotein lipase (Fig.3A) and lecithin cholesterol acyl transferase (Fig.3B) were observed in plasma of fluoride intoxicated rats as compared to the normal rats. Pre-administration of EGCG to fluoride rats significantly $(\mathrm{P}<0.05)$ increased the activities of lipoprotein lipase and lecithin cholesterol acyl trans-ferase when compared to fluoride untreated rats.

Table 1: Effect of EGCG on Fluoride Induced Changes in the Serum Hepatic Markers of Control and Experimental Rats.

\begin{tabular}{|c|c|c|c|c|}
\hline Parameter & Control & EGCG & $\mathrm{Fl}$ & EGCG+Fl \\
\hline SGOT (U/I) & $48.06 \pm 0.09^{\mathrm{a}}$ & $50.3 \pm 0.45^{\mathrm{a}}$ & $67.02 \pm 0.25^{\mathrm{c}}$ & $50.25 \pm 0.15^{\mathrm{d}}$ \\
\hline SGPT (U/I) & $31.11 \pm 0.72^{\mathrm{a}}$ & $33.43 \pm 0.56^{\mathrm{ab}}$ & $43.51 \pm 0.96^{\mathrm{c}}$ & $30.96 \pm 0.54^{\mathrm{cd}}$ \\
\hline ALP (U/I) & $61.22 \pm 0.57^{\mathrm{a}}$ & $63.1 \pm 0.42^{\mathrm{ab}}$ & $82.31 \pm 0.32^{\mathrm{c}}$ & $62.52 \pm 0.1^{\mathrm{d}}$ \\
\hline $\mathrm{ACP}(\mathrm{U} / \mathrm{I})$ & $40.3 \pm 0.1^{\mathrm{a}}$ & $42.05 \pm 0.65^{\mathrm{a}}$ & $71.43 \pm 0.26^{\mathrm{c}}$ & $50.03 \pm 0.14^{\mathrm{cd}}$ \\
\hline
\end{tabular}

Values are given as mean \pm SD for six rats in each group. Values with different superscript letter. (a-d) in the same row or column differ significantly at $\mathrm{p}<0.05$ (DMRT)

a) Values not differ significantly from control group at $(\mathrm{P}<0.05)$.

b) Values differ significantly from control group at $(\mathrm{P}<0.05)$.

c) Values differ significantly from EGCG group at $(\mathrm{P}<0.05)$.

d) Values differ significantly from Fluoride group at $(\mathrm{P}<0.05)$.

Table 2: Effect of EGCG on Fluoride Induced Changes in the Plasma Glucose, Liver Glycogen, Hexokinase and G6PD Activities of Control and Experimental Rats

\begin{tabular}{|c|c|c|c|c|}
\hline Parameters & Control & EGCG & $\mathrm{Fl}$ & $\mathrm{EGCG}+\mathrm{Fl}$ \\
\hline $\begin{array}{l}\text { Glucose }(\mathrm{mg} / \mathrm{dl}) \\
\text { Glycogen }(\mathrm{mg} / \mathrm{g}) \\
\text { Hexokinase } \\
\text { (U/mg /protein/min) } \\
\text { G6PD (U/mg protein/min) }\end{array}$ & $\begin{array}{l}93.44 \pm 1.31^{\mathrm{a}} \\
16.97 \pm 0.21^{\mathrm{a}} \\
8.32 \pm 0.17^{\mathrm{a}} \\
0.17 \pm 0.03^{\mathrm{a}}\end{array}$ & $\begin{array}{l}120.04 \pm 1.60^{b} \\
15.11 \pm 0.18^{b} \\
6.33 \pm 0.20^{b} \\
0.33 \pm 0.02^{b}\end{array}$ & $\begin{array}{l}188.72 \pm 0.88^{\mathrm{c}} \\
10.09 \pm 0.31^{\mathrm{c}} \\
3.70 \pm 0.10^{\mathrm{c}} \\
0.48 \pm 0.02^{\mathrm{c}}\end{array}$ & $\begin{array}{l}150.43 \pm 1.23^{\mathrm{d}} \\
13.10 \pm 0.27^{\mathrm{d}} \\
5.04 \pm 0.16^{\mathrm{d}} \\
0.28 \pm 12^{\mathrm{d}}\end{array}$ \\
\hline
\end{tabular}

Values are given as mean \pm SD for six rats in each group. Values with different superscript letter.

$(a-d)$ in the same row or column differ significantly at $\mathrm{p}<0.05$ (DMRT).

a) Values not differ significantly from control group at $(\mathrm{P}<0.05)$.

b) Values differ significantly from control group at $(\mathrm{P}<0.05)$

c) Values differ significantly from EGCG group at $(\mathrm{P}<0.05)$.

d) Values differ significantly from Fluoride group at $(\mathrm{P}<0.05)$.

Table 3: Effect of EGCG on the Level of Plasma Cholesterol, Triglycerides, Phospholipids, Free Fatty Acids and Lipoproteins Concentrations in Control and Experimental Rats.

\begin{tabular}{|c|c|c|c|c|}
\hline Parameters & Control & EGCG & $\mathrm{Fl}$ & $\mathrm{EGCG}+\mathrm{Fl}$ \\
\hline Cholesterol $(\mathrm{mg} / \mathrm{dl})$ & $96.8 \pm 4.01^{\mathrm{a}}$ & $95.5 \pm 3.7^{\mathrm{a}}$ & $248.9 \pm 9.4^{b}$ & $121.2 \pm 4.4^{\mathrm{c}}$ \\
\hline Triglycerides $(\mathrm{mg} / \mathrm{dl})$ & $78.5 \pm 2.9^{\mathrm{a}}$ & $76.1 \pm 2.7^{\mathrm{a}}$ & $257.1 \pm 8.9^{b}$ & $101.6 \pm 3.4^{c}$ \\
\hline Phospholipids (mg/dl) & $87.6 \pm 2.8^{\mathrm{a}}$ & $85.2 \pm 2.7^{\mathrm{a}}$ & $179.4 \pm 5.5^{\mathrm{b}}$ & $134.2 \pm 4.2^{c}$ \\
\hline Free fatty acids (mg/dl) & $80.5 \pm 2.3^{\mathrm{a}}$ & $77.1 \pm 2.1^{\mathrm{a}}$ & $175.1 \pm 4.7^{\mathrm{b}}$ & $80.8 \pm 2.1^{\mathrm{ac}}$ \\
\hline VLDL-C (mg/dl) & $20.7 \pm 0.5^{\mathrm{a}}$ & $21.4 \pm 0.7^{\mathrm{a}}$ & $58.3 \pm 2.0^{\mathrm{b}}$ & $28.3 \pm 0.9^{c}$ \\
\hline LDL-C (mg/dl) & $44.4 \pm 1.5^{\mathrm{a}}$ & $42.8 \pm 1.3^{\mathrm{a}}$ & $138.1 \pm 5.3^{\mathrm{b}}$ & $61.6 \pm 2.3^{c}$ \\
\hline HDL-C (mg/dl) & $29.9 \pm 1.0^{\mathrm{abc}}$ & $30.6 \pm 1.2^{\mathrm{ac}}$ & $20.3 \pm 5.1^{\mathrm{b}}$ & $25.3 \pm 1.3^{\mathrm{abc}}$ \\
\hline
\end{tabular}

Values are given as mean \pm SD for six rats in each group. Values with different superscript letter.

$(\mathrm{a}-\mathrm{c})$ in the same row or column differ significantly at $\mathrm{p}<0.05$ (DMRT).

a) Values not differ significantly from control and EGCG group at $(\mathrm{P}<0.05)$.

b) Values differ significantly from control and drug control group at $(\mathrm{P}<0.05)$. 
c) Values differ significantly from Fl group at $(\mathrm{P}<0.05)$.
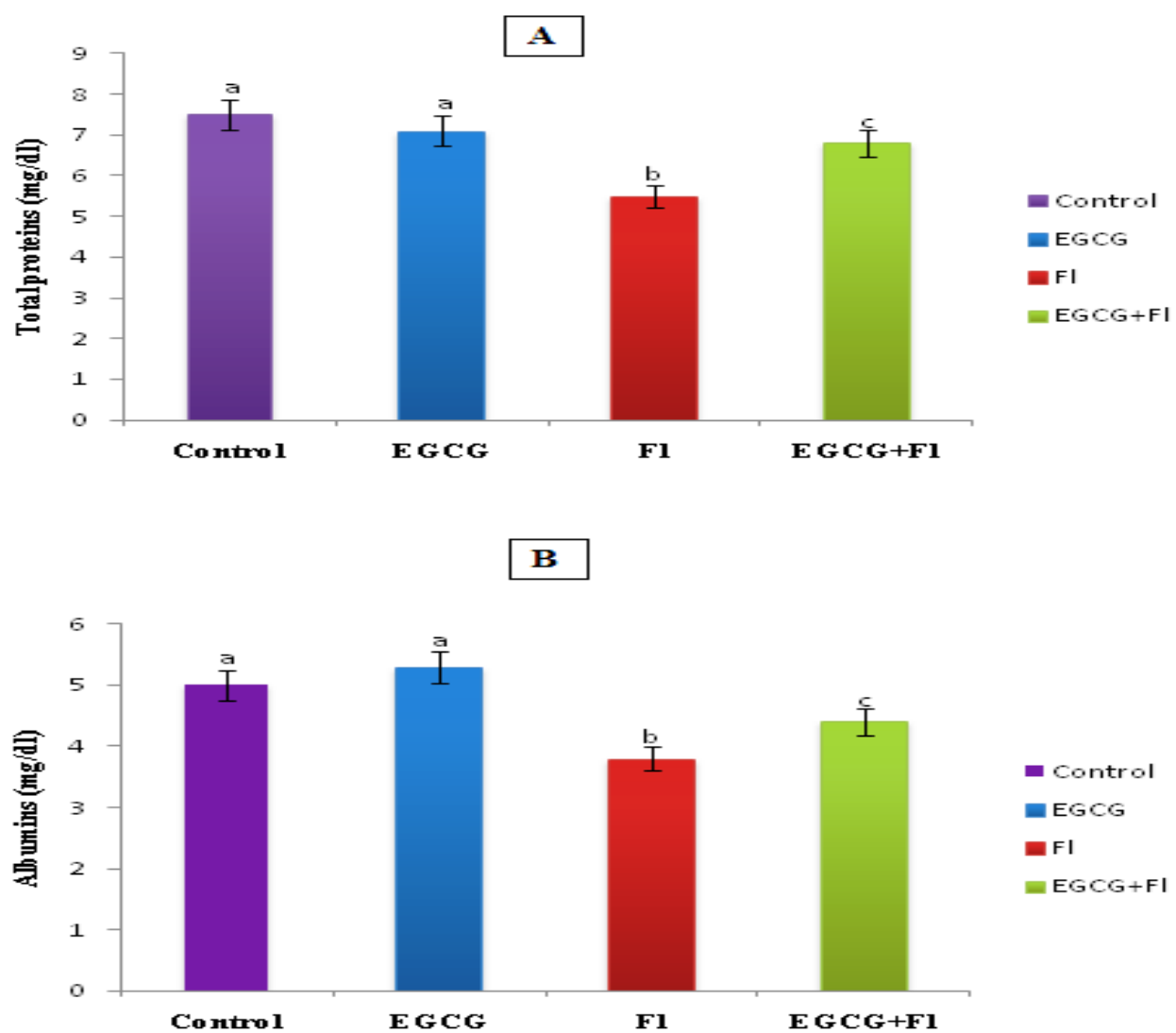

Fig. 2: Effect of EGCG on Fluoride Induced Changes in the Levels of Total Protein (A) and Albumins (B) in Control and Experimental Groups. Values are Mean \pm SD for Six Rats in Each Group. Values Not Sharing a Common Superscript Letters (A, B And C) Differ Significantly at P<0.05 (DMRT).
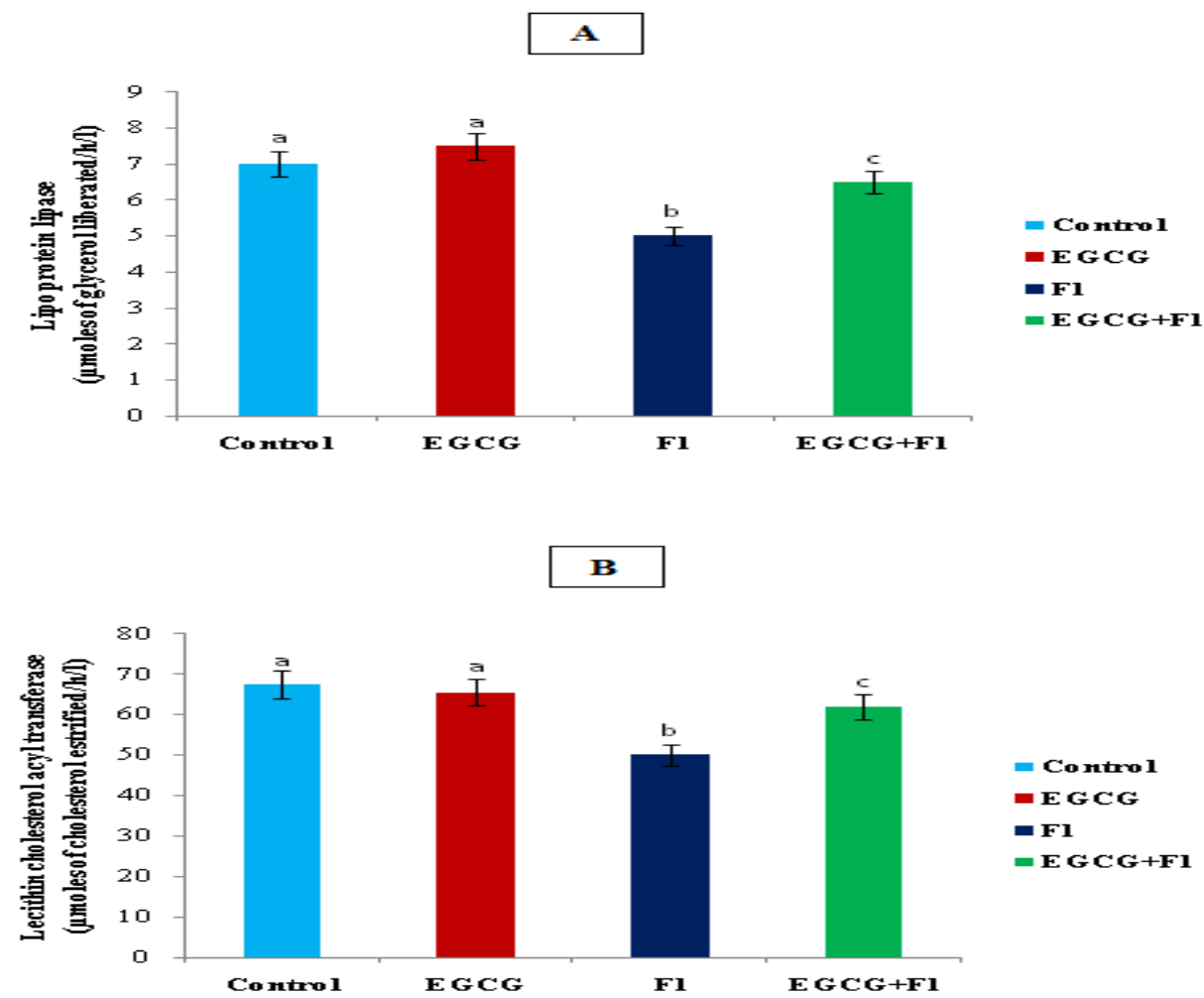

Fig. 3: Effect of EGCG on Fluoride Induced Changes in the Lipoprotein Lipase (A) and Lecithin Cholesterol Acyltransferase (B) in Control and Experimental Groups. Values are Mean \pm SD for Six Rats in Each Group. Values Not Sharing a Common Superscript Letters (A, B and C) Differ Significantly at $\mathrm{P}<0.05$ (DMRT). 


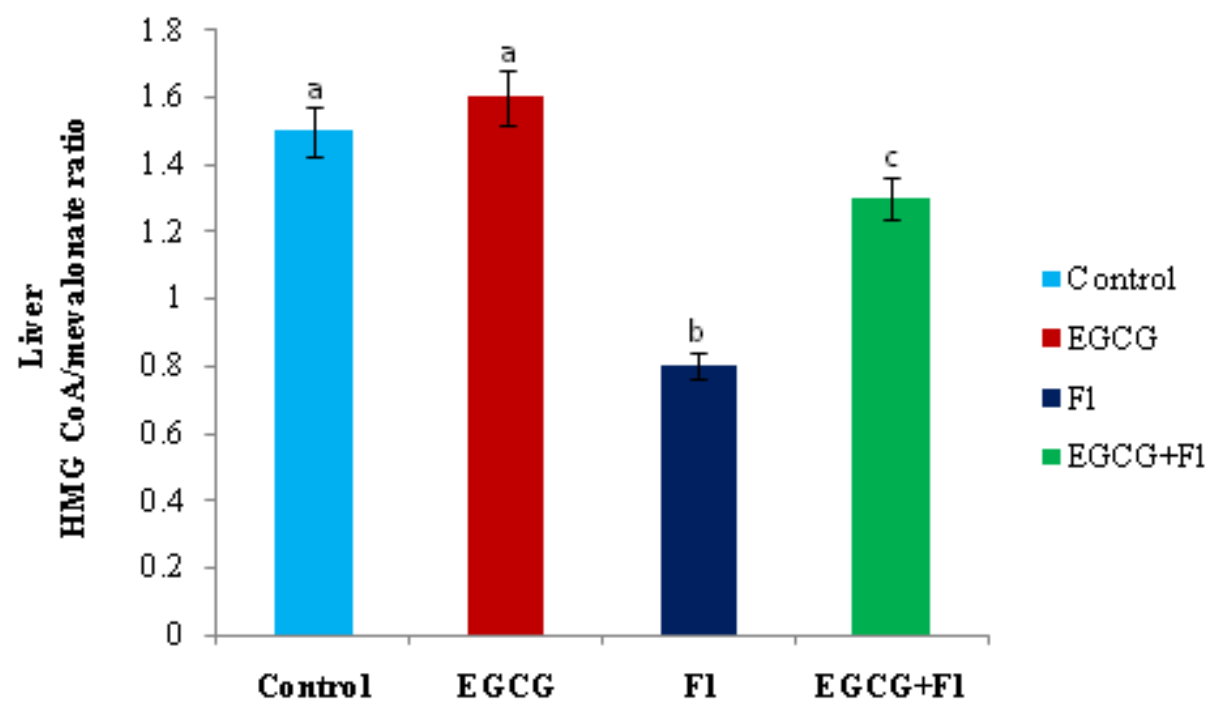

Fig. 4: Effect of EGCG on Fluoride Induced HMG Coa in Liver of Control and Experimental Rats. Values are Mean \pm SD for Six Rats in Each Group. Values Not Sharing A Common Superscript Letters (A, B and C) Differ Significantly at P<0.05 (DMRT).

\subsection{Effect of EGCG on liver marker enzyme}

Figure 4 illustrate the changes in the activities of liver HMG-CoA reductase in the control and experimental rats. A significant $(\mathrm{P}<0.05)$ increase in the activity of HMG-CoA reductase was observed in the liver of fluoride intoxicated rats. Pre-oral treatment of EGCG to fluoride rats significantly $(\mathrm{P}<0.05)$ decreased the activity of HMG-CoA reductase in the liver tissue in comparison with fluoride alone treated rats. EGCG alone treated rats showed no significant difference in the HMG-CoA reductase.

\subsection{Effect of EGCG on liver lipid profiles}

Table 4 depicts the levels of cholesterol, triglycerides, phospholipids and free fatty acids in the liver of control and experimental groups of rats. There was a significant $(\mathrm{P}<0.05)$ increase in the cholesterol, triglycerides, phospholipids and free fatty acids in the liver of fluoride intoxicated rats. Following the pre-oral administration of EGCG significantly $(\mathrm{P}<0.05)$ decreased these levels were found to be similar to those in control rats.

Table 4: Effect of EGCG on Fluoride Induced Cholesterol, Triglycerides, Phospholipids, and Free Fatty Acids in the Liver of Control and Experimental Rats.

\begin{tabular}{lllll}
\hline Parameters & Control & EGCG & Fl & $\begin{array}{l}\text { EGCG }+ \\
\text { Fl }\end{array}$ \\
\hline Cholesterol $(\mathrm{mg} / \mathrm{dl})$ & $12.6 \pm$ & $11.6 \pm$ & $20.7 \pm$ & $15.4 \pm$ \\
Triglycerides & $1.1^{\mathrm{a}}$ & $1.3^{\mathrm{a}}$ & $1.3^{\mathrm{b}}$ & $2.5^{\mathrm{c}}$ \\
(mg/dl) & $12.3 \pm$ & $11.2 \pm$ & $18.5 \pm$ & $13.4 \pm$ \\
Phospholipids & $1.4^{\mathrm{a}}$ & $1.2^{\mathrm{a}}$ & $2.4^{\mathrm{b}}$ & $1.3^{\mathrm{c}}$ \\
(mg/dl) & $20.9 \pm$ & $21.7 \pm$ & $30.3 \pm$ & $24.6 \pm$ \\
Freefatty acids & $2.4^{\mathrm{a}}$ & $1.8^{\mathrm{a}}$ & $3.5^{\mathrm{b}}$ & $4.4^{\mathrm{c}}$ \\
(mg/dl) & $13.9 \pm$ & $13.5 \pm$ & $19.1 \pm$ & $16.4 \pm$ \\
& $1.5^{\mathrm{a}}$ & $1.3^{\mathrm{a}}$ & $1.4^{\mathrm{b}}$ & $3.4^{\mathrm{c}}$ \\
\hline
\end{tabular}

Values are given as mean \pm SD for six rats in each group. Values with different superscript letter.

$(\mathrm{a}-\mathrm{c})$ in the same row or column differ significantly at $\mathrm{p}<0.05$ (DMRT).

a) Values not differ significantly from control and EGCG group at $(\mathrm{P}<0.05)$.

b) Values differ significantly from control and drug control group at $(\mathrm{P}<0.05)$.

c) Values differ significantly from $\mathrm{Fl}$ group at $(\mathrm{P}<0.05)$.

\subsection{Effect of EGCG on faecal cholesterol and bile acid content}

Figure 5 demonstrate the effect of EGCG on fluoride induced changes in the fecal cholesterol and bile acid content in control and experimental rats. Fluoride intoxicated rats showed higher levels of faecal cholesterol (Fig 5A) and bile acid (Fig 5B) content when compared to the control group. However, oral administration of EGCG significantly $(\mathrm{P}<0.05)$ increased the fecal cholesterol and bile acid contents when compared to control and fluoride intoxicated group. While EGCG administrated rat also showed increased levels of fecal cholesterol and bile acid content when compared to control.

\subsection{Effect of EGCG on liver histology}

Fig.6A-E depicts the photomicrographs of hematoxylin-eosin stained liver tissues of control and experimental animals. Liver section from normal and drug control rats showed normal histoarchitecture with well-defined manner (Figs. 6A and B). The liver cells of animals exposed to fluoride for 4 weeks suffered several pathological changes, such as extensive degeneration of hepatocytes with focal necrosis, bridging necrosis, inflammation, inflammatory cell infiltration, portal inflammation, and fatty degenerative changes, etc., (Figs. 6C and 5D). Pre-administration of EGCG effectively attenuated the histopathological abnormalities evoked by exposure to fluoride (Fig. 6E). 


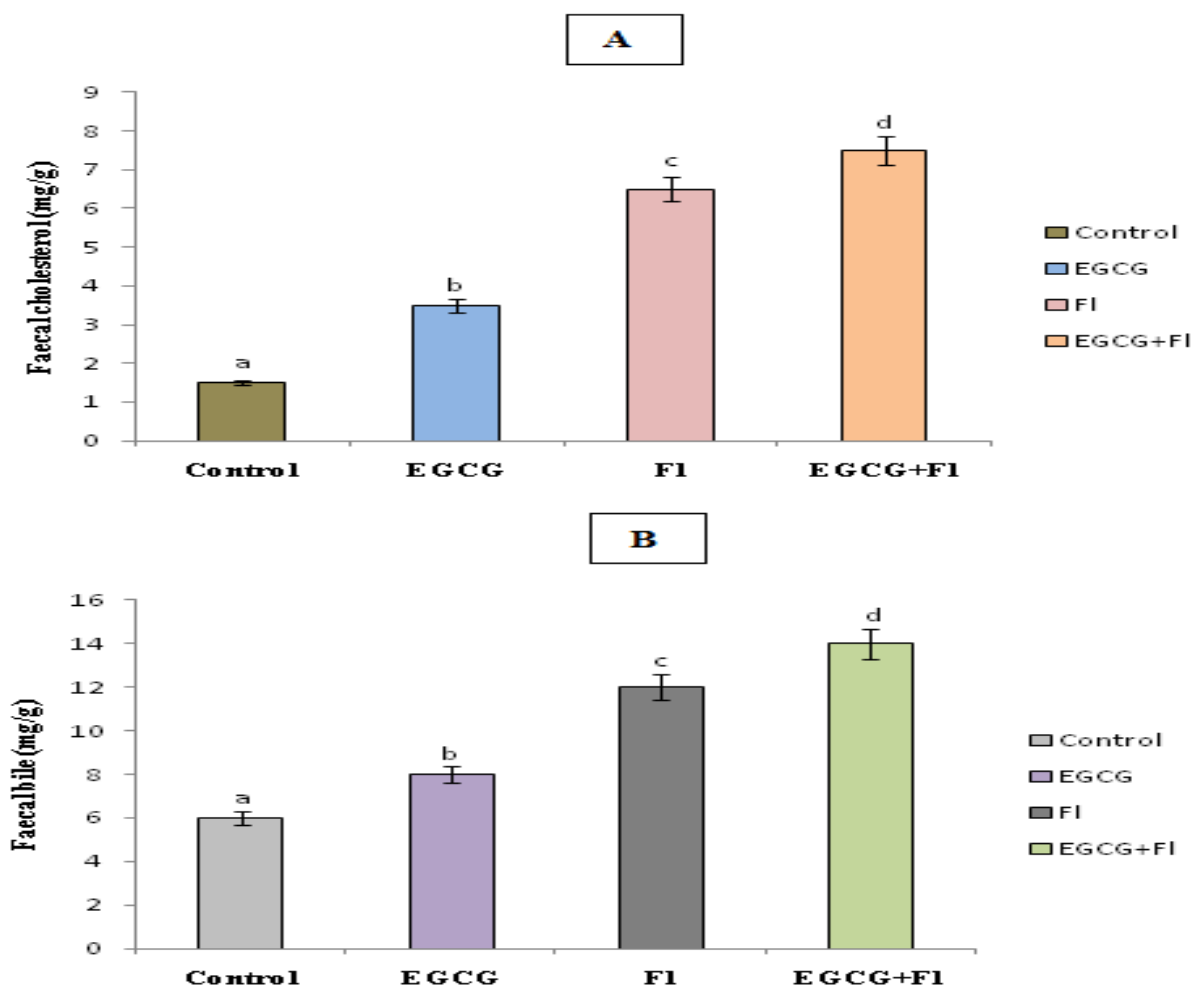

Fig. 5: Effect of EGCG on Fluoride Induced Serum Faecal Cholesterol and Faecal Bile Acid in Control and Experimental Rats. Values are Mean \pm SD for Six Rats in Each Group. Values Not Sharing A Common Superscript Letters (A, B C And D) Differ Significantly at P<0.05 (DMRT).

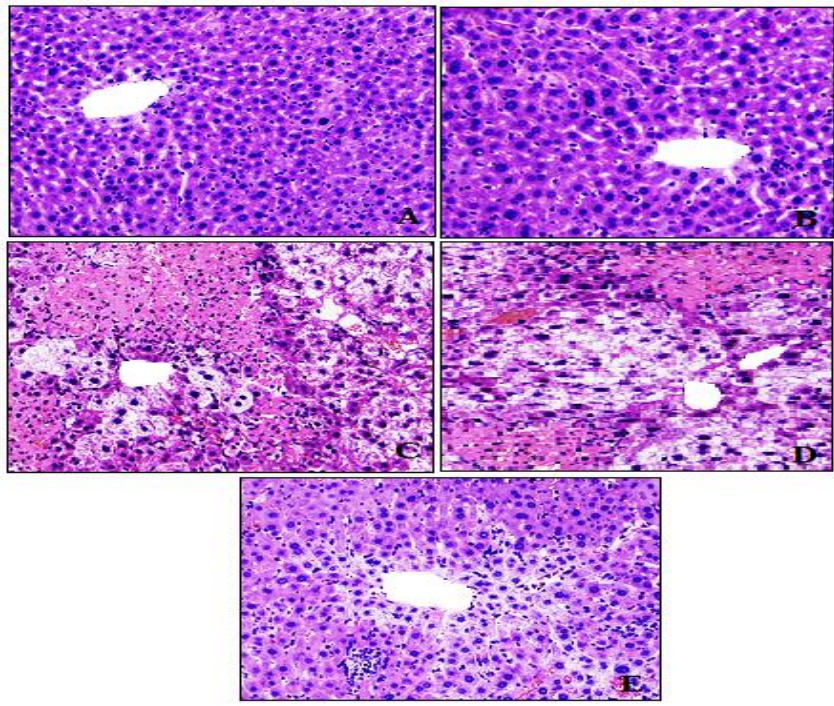

Fig. 6: Representative Photomicrographs from Liver Sections of Control and Experimental Male Wistar Rats Stained with Haematoxylin and Eosin (A) Section of Control Liver Showing Normal Arrangement of Sinusoids and Hepatocytes. (B) Section of Liver Treated with Epigallocatechin Gallate (EGCG) Alone Showing the Normal Histoarchitectural Pattern. (C $\&$ D) Section of Liver Exposed to Fl Showing the Extensive Inflammation, Dilated Sinusoids, Degeneration of Hepatocytes with Necrosis, Vacuolization, and Inflammatory Cell Infiltration, Fatty Degeneration of Hepatocytes (E) Section of Liver Treated with EGCG and Fl Showing Significant Improvement of Hepatic Histoarchitecture with Mild Infiltration.

\section{Discussion}

Liver is an important organ for metabolism and detoxification of any substances. Leakage of hepatospecific enzymes into blood serum has been considered an indicator of hepatic damage and dysfunction. Fluoride is known to cause hepatic tissue injury as reflected by a significant increase in serum hepatic marker enzymes indicating the cellular leakage and loss of functional integrity of the hepatic membrane architecture (Thangapandiyan \& Miltonprabu 2013). In the present study, Fluoride intoxication caused a significant increase in the activities of SGOT, SGPT, ALP and ACP, due to hepatocyte membrane damage. Reactive oxygen species (ROS) elicited by fluoride are implicated as important pathological mediators in many types of disorders. Their presence is reflected by increased oxygen radical generation and caused lipid peroxidation in the liver (Chinoy \& Memon 2001). Rzeuski et al. (1998) reported that excessive ROS persuaded by fluoride can induce lipid peroxidation, which reduced activities of antioxidant enzymes, which may result in the damage of membrane integrity that leads to leakage of liver specific enzymes into blood. Administration of EGCG remarkably improved the alterations in hepatic functions induced by fluoride. Because, EGCG has already been reported to exhibit membrane-stabilization properties against fluoride induced ROS-mediated oxidative hepatocellular injury (Thangapandiyan \& Miltonprabu 2013).

In the present study fluoride-exposed rats exhibited a significant elevation in blood glucose and G6PD levels with decreased hepatic glycogen and hexokinase activity. Administration of EGCG resulted in a substantial lowering of blood glucose levels and hepatic G6PD activity along with improvements in hepatic glycogen content and hexokinase activity in fluoride-exposed animals. The decline in hexokinase activity in fluoride administered animals could be due to lowered insulin levels (Garcia-Montalvo et al. 2009). The increase in hexokinase activity could be due to an insulin restoratory potential of EGCG (Lin \& Lin 2008).These antihyperglycaemic activities of EGCG could be ascribed to the secondary metabolites (polyphenols and flavonoids) present in green tea leaves. Polyphenols are known to inhibit glucose absorption in the gut, inhibit peripheral tissue glucose uptake by glucose transporters (Pandey \& Rizvi 2009), protect pancreatic b cells and inhibit insulin resistance (Zunino \& Storms 2007). Flavonoids are reported to possess antidiabetogenic potential. This purported antidiabetogenic activity of flavonoids was attributed to an increase in pancreatic secretion of insulin from $b$ cells or its release from bound insulin (Sharma et al. 2003). Therefore, the phytometabolites present in EGCG may have contributed individually or synergistically to the declined levels of glucose and hepatic G-6-Pase while enhancing the activity of hexokinase and improving the glycogen content in the liver. 
Irregular protein metabolism is considered a sign of hepatic dysfunction. In the present study, the administration of fluoride resulted in a significant decrease in the attention of total protein and albumin as compared to the control group. Earlier studies reported a similar reduction in protein content in fluoride treated animals and related it to inhibition of decarboxylation of branched chain amino acids and simultaneously promoting protein breakdown (Shashi et al. 1992). Fluoride affects cellular protein synthesis mainly due to the impairment of peptide chain initiation (Godehaux \& Atwood 1976). Fluoride spawned free radicals down-regulate the activity of enzymes important in the polymerization of amino acids, thus inhibiting the process of elongation of peptides (Hordyjewska \& Pasternak 2004). Furthermore, the observed decrease in protein content may be explained in part by the reduction in insulin level since insulin has an anabolic effect on protein metabolism in that it stimulates protein synthesis and retards protein degradation (Murray et al. 1999). Previous reports have shown that protein synthesis is decreased in all tissues due to absolute or relative deficiency of insulin (Chatterjea \& Shinde 1994). EGCG Supplementation improved the reduced levels of total proteins and albumin of fluoride intoxicated rats. This tendency to increase the level of protein contents could be ascribed to suppression of fluoride induced oxidative stress and liver damage with the subsequent improvement of natural antioxidant in the body against free radicals.

A high intake of fluoride result in various biochemical changes, including alternation in lipid metabolism in the liver (Thangapandiyan \& Miltonprabu 2013). In the present study, a significant increase level of serum lipid profiles (cholesterol, triglycerides, phospholipids, free fatty acids and phospholipids) and lipoproteins were observed. The changes in the serum lipid profiles and other lipid compounds noted in the fluoride treated rats may be explained by the increased activity of HMG-CoA via accumulation of ROS releasing inflammatory cytokines in the liver (Afolabi et al. 2013). The changes in the activity of HMG-CoA reductase may depress LDL receptor gene expression. Defects in LDL receptor interfere with cholesterol uptake from the blood stream, which in turn causes excess cholesterol synthesis in liver and high levels of plasma cholesterol and LDL-C (Rupal et al 2012). Lipase enzyme responsible for the controlling of triglyceride accumulation in the liver, but the buildup of ROS induced by fluoride inhibit the lipase enzyme and increase the triglycerides (TG) level in the tissue and serum. Increasing levels of TG leads to elevation of VLDL-C in the serum because VLDL particles are the main transporters of TG in plasma [52]. The overproduction of hepatic VLDL-C and impaired catabolism of TG-rich particles may lead to hypertriglyceridemia. Lowered level of plasma HDL$\mathrm{C}$ implies the altered metabolism of the major HDL apoprotein AI in the liver (Suttie \& Phillips 1960). Phospholipids (PL) and free fatty acids (FF) are consisting of rich polyunsaturated compounds, which are easily susceptible to reactive oxygen species (Doroshow 1983). Formations of reactive oxygen species (ROS) induced by fluoride may affect the membrane-bound enzymes, and permeability of ions by which increase the PL levels in serum and liver tissue. Pre-treatment of EGCG in fluoride treated rats significantly has normalized the serum lipid profiles (cholesterol, triglycerides, phospholipids and free fatty acids) and lipoproteins through their antilipoperoxidative and antioxidant actions, which inhibit the extensive accumulation of cholesterol and oxidized lipid components as well as prevent hypercholesterolemia.

HMG-CoA reductase is the rate-limiting enzyme in cholesterol biosynthesis. An increase in the activity of HMG-CoA reductase leads to the excessive production and accumulation of cholesterol resulting in the formation of foam cells, a pre- requisite step in the development of atherosclerosis (Easterbauer et al. 1992). Rising evidence indicates that the activity of HMG-CoA reductase is increased in fluoride intoxicated rats (Rupal et al. 2012) due to deficiency of insulin is associated with increased HMG- CoA reductase activity. Fluoride induced ROS has the ability to inhibit lipoprotein lipase and lecithin cholesterol acyl transferase which was also responsible for the elevated HMG-CoA levels in the liver tissue. In the present study, significantly increased HMG-CoA activity was observed in fluoride intoxicated rats. Our results of elevated HMG-CoA were corroborated with the existing previous reports (Miltonprabu et al. 2010; Nareshkumar et al. 2013). Preadministration of EGCG to fluoride intoxicated rats had a positive effect on the HMG-CoA enzyme of lipid metabolism. This is due to the activities of lipoprotein lipase and lecithin cholesterol acyl transferases were increased in fluoride rats treated with EGCG. Restoration of the lipid profile in fluoride rats could be the lipid lowering activities of EGCG could also due to its insulinotropic effect (Chih-Li et al. 2008).

From the present observation fluoride treated rats showed decreased levels of lipoprotein lipase in the plasma. Our findings of decreased lipoprotein lipase by fluoride are in tune with the streptozotocin $(45 \mathrm{mg} / \mathrm{kg} / \mathrm{BW})$ treated rats for 30days (Nareshkumar et al. 2013). It is one of the lipid metabolizing enzymes and its activity was controlled by the insulin. The decreased lipoprotein lipase activity may contribute by the fluoride induced free radicals, which were actively oxidize the lipid molecules and significantly increased HMG-CoA and triglyceride levels in the liver and plasma of fluoride intoxicated rats by which lowered lipoprotein lipase (Bhardwaj \& Shashi 2013). In this circumstance, the pre-oral administration of EGCG was significantly increased the lipoprotein lipase activity by the direct reduction of glucose in the blood of fluoride intoxicated rats. This may be due to the enhanced free radicals quench and activation of $\beta$-cells to secrete insulin for decreasing the mobilization of free fatty acids and triglycerides from the fat depots (Suqing et al. 2014).

Lecithin cholesterol acyl transferase is one of the key enzymes involved in HDL-C metabolism. It is esterifies free cholesterol to cholesteryl esters in serum (Chtubek et al. 2003). The formation and accumulation of cholesteryl esters in the core of HDL results from the removal of cholesterol from the surface lipoprotein with simultaneous efflux through cell membranes into HDL-C (Suqing et al. 2014). In the present study, the decreased activity of lecithin cholesterol acyl transferase was observed in the plasma of fluoride intoxicated rats, which was in accordance with the previous reports (Chtubek et al. 2003; Nareshkumar et al. 2013). Fluoride is a well-known inhibitor of lipases, phosphatases, esterases, and acetyl Co-A synthetase. It interferes with fatty acid oxidation which results in decreased synthesis of lecithin cholesterol acyl transferase in the plasma (Machoy-Mokrzynska et al. 1994). Pre oral administration of EGCG to fluoride treated rats had a positive effect on the marker enzyme of lecithin cholesterol acyl transferase. The lipid lowering activities of EGCG could be due to its strong antioxidants and hydrogen donating property to stabilize the lipid membranes.

In the present study, faecal cholesterol and bile were significantly increased in fluoride intoxicated rats, which was similar to the previous report of Rupal et al. (2012). The effect of fluoride on serum fecal cholesterol levels could be explained by several mechanisms: (1) an increased effectiveness of the feedback mechanism for cholesterol synthesis, (2) a decreased absorption of cholesterol from the intestine, (3) an increased conversion of cholesterol to bile salts, and (4) a decreased absorption of bile salts from the intestine resulting in an increased conversion of cholesterol to bile acids. The lack of response to the increased levels of fluoride in the absence of exogenous cholesterol suggests, that fluoride does not influence endogenous cholesterol metabolism [64]. The fecal bile acid increased due to fluoride induced ROS, which is responsible for the inhibition of HDL-C synthesized in the liver and intestinal cells. However, pathophysiological accumulation of bile acids can elicit cytotoxicity, and elevated concentrations are associated with liver injury (Dewaynteownsen \&Dleonsinge 1977). Pre-administration of EGCG to fluoride intoxicated rats showed a significant increase of fecal cholesterol and fecal bile. This could be due to the rich polyphenolic fiber contents of green teas contained dietary EGCG found to increase cholesterol excretion by interfering with the enterohepatic circulation of cholesterol and bile acid. The presence of pholyphenol and flavonoids in 
EGCG also could be responsible for the antihypercholesterolaemic effects on fluoride intoxicated rats.

The histological results also strongly support our biochemical findings that EGCG protects against the fluoride-induced oxidative stress mediated hepatic (Fig. 5) injury. The histological findings from the liver of fluoride treated rats showed the necrosis, inflammatory cell infiltration, dilation of sinusoidal spaces, and inflammation (Fig. 5C\&D). This could be due to the accumulation of free radicals as a consequence of increased lipid peroxidation by free fluoride- ions. The increased formation of lipid peroxides and protein carbonyls leads to the damage of membrane integrity and other pathological alterations in the fluoride treated liver tissue. Pre-treatment with EGCG markedly lessened the pathological changes provoked by fluoride, which is quite appreciable. It can be attributed to the antiradical, antioxidant, anti-inflammatory and chelating efficacy of EGCG, which significantly reduced the oxidative stress, leading to the reduction of pathological alterations and restoration of normal physiological state of an organism. Further, the membrane stabilizing properties of EGCG might be helpful to improve the pathological alterations caused by fluoride in the both tissues of rats.

Scientific reports showed that catechins possess many of the structural components that contribute to their antioxidant property. Catechins have a gallate moiety esterified at the $3^{\text {rd }}$ position on the $\mathrm{C}$ ring, the catechol groups (3,4,5-trihydroxyl groups) on the $\mathrm{B}$ ring and the hydroxyl groups at the $5^{\text {th }}$ and $7^{\text {th }}$ positions on the $\mathrm{A}$ ring (Fig. 1). The potent free radical scavenging activity of EGCG was attributed to the presence within the $\mathrm{C}$ ring gallate group. The observation was also made that the more hydroxyl groups the catechin (EGCG) possesses the more effective for scavenging free radicals (Zhao et al. 2001)

\section{Conclusion}

In conclusion, the present investigation depicts that the administration of EGCG to fluoride intoxicated rat's decreases the ROS mediated metabolisms in liver tissue lipid profiles and restored the regulatory enzymes involved in the carbohydrates, protein, lipids and lipoprotein metabolism and maintains at a normal level. Therefore, in light of our observations, we conclude that EGCG could be used as a component in foods to promote the health of people living in endemic fluorosis areas as a means to ameliorate fluoride-induced ailments.

\section{Conflicts of interest}

The author declares that there are no conflicts of interest.

\section{Acknowledgement}

The authors acknowledge the Professor and Head of the Department of Zoology, Annamalai University, and the University Grant Commission for staff assisted programme (UGC-SAP) for their generous support in this work.

\section{References}

[1] Afolabi OK, Oyewo EB, Adekunle AS, Adedosu OT, Adedeji AL (2013) Oxidative indices correlate with dyslipidemia and proinflammatory cytokine levels in fluoride exposed rats. Arh High Rads Toksikol. 64 (4):521-9. http://dx.doi.org/10.2478/10004-1254-642013-2351

[2] Baginsky ES, Foa PP, Zad B (1974) Glucose-6-phosphatase. In Bergemeyer HU, editor. Methods of enzymatic analysis. 2nd Ed. New York: Academic press. 788-92. http://dx.doi.org/10.1016/B978-0-12091302-2.50072-4.

[3] Barbier O, Arreola-Mendoza L, Razo LMD (2010) Molecular mechanisms of fluoride toxicity. Chem Biol Interact. 2010; 188:319-33. http://dx.doi.org/10.1016/j.cbi.2010.07.011.
[4] Bhardwaj M, Shashi A (2013) Dose effect relationship between high fluoride intake and biomarkers of lipid metabolism in endemic fluorosis. Biomedicine \& Preventive Nutrition. 3:121-127. http://dx.doi.org/10.1016/j.bionut.2012.10.006.

[5] Brandstup N, Kirk JE, Bruni C (1957) Determination of hexokinase in tissues. J Gerontol. 12:166-71

[6] Chatterjea MN, Shinde R (1994) Metabolism of carbohydrate. Textbook of Medical Biochemistry. Jaypee Brothers Medical Publishers. New Delhi, India, p. 421.

[7] Chih-Li Lin and Jen-Kun Lin (2008) Epigallocatechin gallate (EGCG) attenuates high glucose-induced insulin signaling blockade in human hepG2 hepatoma cells. Mol. Nutr. Food Res. 52: 930 - 939. http://dx.doi.org/10.1002/mnfr.200700437.

[8] Chinnoy NJ (1991) Effects of sodium fluoride on physiology of some animals and human beings. Indian J. Environ. Toxicol. 1: 17-32.

[9] Chinnoy NJ (2003) Fluoride stress on antioxidant defense systems. Fluoride. 36:138-141

[10]Chinoy NJ, Memon MR (2001) Beneficial effects of some vitamins and calcium on fluoride and aluminium toxicity on gastrocnemius muscle and liver of male mice. Fluoride 34:21-33.

[11]Chlubek D (2003) Fluoride and oxidative stress. Fluoride. 36 (4): $217-228$

[12]Chtubek D, Grucka-Mamczar E, Birkner E, Potaniak R, StawiarskaPieta B, Duliban H (2003) Activity of pancreatic antioxidative enzymes and malondialdehyde concentrations in rats with hyperglycemia caused by fluoride intoxication. Trace Elem. Med. Biol. 17 (1): 57-60. http://dx.doi.org/10.1016/S0946-672X (03)80047-0.

[13]Devika PT, Stanely Mainzen Prince P (2008) Epigallocatechin-gallate (EGCG) prevents mitochondrial damage in isoproterenol-induced cardiac toxicity in albino Wistar rats: A transmission electron microscopic and in vitro study. Pharmacol. Res. 57: 351-357. http://dx.doi.org/10.1016/j.phrs.2008.03.008.

[14]Dewaynteownsen and Dleonsinge (1977) Effect of Fluoride on the Serum Lipids of Guinea Pigs. J. Nutr. 107: 97-103.

[15]Doroshow JH (1983) Effect of anthrocycline antibiotics on oxygen radical formation in rat heart. Cancer Res 43:460-72.

[16]Doumas BT, Watson WA, Biggs HG (1971) Albumin slandered and the measurements of serum albumin with bromcresol green. Clin. Chem. Acta. 31:87-96. http://dx.doi.org/10.1016/0009-8981 (71) $90365-2$.

[17]Easterbauer H, Gebick J, Phal H, Jurgens G (1992) the role of lipidperoxidatio- nand antioxidants in the oxidative modifications of LDL. Free Radic. Biol. Med 13, 341-390. http://dx.doi.org/10.1016/0891-5849 (92)90181-F.

[18]Falholt K, Falholt W, Lund B (1973) an easy colorimetric method for routine determination of free fatty acids in plasma. Clin. Chim. Acta. 46: 105-111. http://dx.doi.org/10.1016/0009-8981 (73)90016-8.

[19]Fielding CJ, Fielding PE (1995) Molecular physiology of reverse cholesterol transport. J. Lipid Res 36: 211-228.

[20]Fiske CH, Subbarow Y (1925) the colorimetric determination of phosphorus. J Biol Chem 66:375-400.

[21]Folch J, Lees M, Solane SGH (1957) A simple method for isolation and purification of total lipids from animal tissues. J. Biol. Chem .226:497-509.

[22]Fossati P, Lorenzo P (1982) Serum triglycerides determined calorimetrically with an enzyme that produces hydrogen peroxide. Clin. Chem. 28:2077-2080.

[23]Garcia-Montalvo EA, Reyes-Perez H, Del-Razo LM (2009) Fluoride exposure impairs glucose tolerance via decreased insulin expression and oxidative stress. Toxicology 263:75-83. http://dx.doi.org/10.1016/j.tox.2009.06.008.

[24]Godehaux W, Atwood KC (1976) Structure and function of initiation complexes. J. Biol. Chem 251:292-301.

[25] Gomez HC, Franco M, Luc G, Montano LF, Masso F, PosadasRomero C (2002) Chronic hypothyroidism induces abnormal structure of high-density lipoproteins and impaired kinetics of apolipoprotein A-I in the rat. Metabolism. 51:443-50. http://dx.doi.org/10.1053/meta.2002.31323.

[26] Grucka-Mamczar E, Birkner E, Baszczyk I, Kasperczyk S, Wielkoszyn T, Swietochowska E, Stawiarska-Pie B (2009) The influence of sodium fluoride on antioxidants and the concentration of malondialdehyde in rat blood plasma. Fluoride. 42 (2):101-104

[27]Hitz J, Steinmetz J, Siest G (1983) Plasma lecithin: cholesterol acyltransferase- reference values and effects of xenobiotics. Clin. Chim. Acta .133:85-96. http://dx.doi.org/10.1016/0009-8981 (83)90023-2.

[28]Hofmann AF (1994) Bile Acids. Raven Press, New York.

[29]Hordyjewska A, Pasternak K (2004) Influence of fluoride on organism of human. J. Elementol 9 (4): 883-987. 
[30]Jeng JH, Hsieh CC, Lan WH, Chang MC, Lin SK., Hahn LJ, Kuo MY (1998) Cytotoxicity of sodium fluoride on human oral mucosal fibroblasts and its mechanisms. Cell Biol. Toxicol .14: 383 http://dx.doi.org/10.1023/A:1007591426267.

[31]Kaiek HD, Stellaard F, Kruis W, Paumgartner G (1984) Detection of increased bile acid content in simple stool samples. Clin Chim Acta .140:85-90. http://dx.doi.org/10.1016/0009-8981 (84)90154-2.

[32]Korn ED (1955) Clearing factor: a heparin activated lipoprotein lipase: isolation and characterization of enzyme from normal rats. J. Biol. Chem. 215: 1-26.

[33]Li RW, Douglas TD, Maiyoh GK, Adeli K., Theriault AG (2006) Green tea leaf extract improves lipid and glucose homeostasis in a fructose-fed insulin-resistant hamster model. J. Ethnopharmacol. 104:24-31. http://dx.doi.org/10.1016/j.jep.2005.08.045.

[34] Lin CL and Lin JK (2008) Epigallocatechin gallate (EGCG) attenuates high glucose-induced insulin signaling blockade in human hepG2 hepatoma cells. Mol Nutr Food Res. 52(8):930-9 http://dx.doi.org/10.1002/mnfr.200700437.

[35]Lowry OH, Rosebrough NJ, Farr AL, and Randall RJ (1951) Protein measurement with Folin-phenol reagent. J. Biol. Chem. 193: 265-275.

[36]Machoy-Mokrzynska A Put A, Ceglecka M, Mysliwiec Z (1994) Influence of essential phospholipids (EPL) on selected biochemica parameters of lipid metabolism in rats chronically exposed to ammonium fluoride vapours. Fluoride. 27:201-4.

[37]May Al-Maghrebi Waleed M. Renno Nada Al-Ajmi. (2012) Epigallocatechin-3-gallate inhibits apoptosis and protects testicular seminiferous tubules from ischemia/reperfusion-induced inflammation. Bioch. Biophy. Res. Commun. 420: 434-439. http://dx.doi.org/10.1016/j.bbrc.2012.03.013.

[38]Miltonprabu S, Shagirtha K, Renugadevi J (2010) Amelioration of Cadmium-Induced Oxidative Stress, Impairment in Lipids and Plasma Lipoproteins by the Combined Treatment with Quercetin and $\alpha$ Tocopherol in Rats. Journal of Food Science. Vol. 75, Nr. 7. doi: 10.1111/j.1750-3841.2010.01757.x. http://dx.doi.org/10.1111/j.17503841.2010.01757.x.

[39]Murray RR, Granner DK, Maye, PA, Rodwell VW (1999) Harper's Biochemistry, 25th ed. Appleton and Lange, Stamford, Connecticut. pp, 610-617.

[40]Muruganandan S, Srinivasan K, Gupta S, Gupta PK, Lal J (2005) Effect of mangiferin on hyperglycemia and atherogenicity in streptozotocin diabetic rats. J Ethnopharmacol. 97:497-501. http://dx.doi.org/10.1016/j.jep.2004.12.010.

[41]Nabavi SM, Nabavi SF, Eslami S, Moghaddam AH (2012) In vivo protective effects of quercetin against sodium fluoride-induced oxidative stress in the hepatic tissue. Food Chem. 2012; 132: 931-935. http://dx.doi.org/10.1016/j.foodchem.2011.11.070.

[42] [42] NareshKumar R, Sundaram R, Shanthi P, Sachdanandam P (2013) Protective role of 20-OH ecdysone on lipid profile and tissue fatty acid changes in streptozotocin induced diabetic rats. Eur. J.of Phar. 2013; 698: 489-498.

[43]Pandey KB, Rizvi SI (2009) Current understanding of dietary polyphenols and their role in health and disease. Curr Nutr Food Sci 2009 5:249-63. http://dx.doi.org/10.2174/157340109790218058.

[44]Philipp B, Shapiro DJ (1970) Improved methods for the assay and activation of 3-hydroxy-3-methyl glutaryl coenzyme A reductase. J Lipid Res. 20: 588-593.

[45]Phillips PH, Hart EB (1935) the effect of organic dietary constituent upon chronic fluorine toxicosis in the rat. J Biol Chem. 109:657-663.

[46]Puneet K, Anil K (2009) Protective effects of epigallocatechin gallate following 3-nitropropionic acid-induced brain damage: possible nitric oxide mechanisms. Psychopharmacology. 207:257-270. http://dx.doi.org/10.1007/s00213-009-1652-y.

[47]Rates SM. (2001) Plants as source of drugs. Toxicon. 9:603-13. http://dx.doi.org/10.1016/S0041-0101 (00)00154-9.

[48]Rupal A. Vasant, Narasimhacharya AVRL (2012) Ameliorative effect of tamarind leaf on fluoride-induced metabolic alterations. Environ Health Prev Med. 17:484-493 http://dx.doi.org/10.1007/s12199-0120277-7.

[49]Rupal AV, Dhrutigna RK, Krutika LB, Narasimhacharya AVRL (2010) Therapeutic benefits of glibenclamide in fluoride intoxicated diabetic rats. Fluoride. 43:141-9.

[50]Rzeuski R, Chlubek D, Machoy Z (1998) Interactions between fluoride and biological free radical reactions. Fluoride. 31:43-5.

[51]Seifter S, Dayton S, Novic B, Muntwyler E (1950) Estimation of glycogen with anthrone reagent. Arch Biochem. 25:191-200.

[52] Sharma SB, Nasir A, Prabhu KM, Dev G, Murthy PS (2003) Hypoglycemic and hypolipidemic effects of ethanolic extracts of seeds of Eugenia jambolana in alloxan induced diabetic model of rabbits. J. Ethnopharmacol. $\quad 85: 201-6 . \quad$ http://dx.doi.org/10.1016/S0378 8741(02)00366-5.
[53] Shashi A, Singh JP, Thapar SP (1992) Protein degradation in skeletal muscle of rabbit during experimental fluorosis. Fluoride. 25 (3): 155158.

[54]Singh BN, Shankar S, Srivastava RK (2011) Green tea catechin, epigallocatechin-3- gallate (EGCG): mechanisms, perspectives and clinical applications. Biochem. Pharmacol. 82:1807-1821. http://dx.doi.org/10.1016/j.bcp.2011.07.093.

[55]Snell FD, Snell CT (1953) Colorimetric methods of analysis, vol. 4 New York: D. Van Nostrand. p. 371-7.

[56]Strunecka A, Patocka J, Blaylokkck RL, Chinoy NJ (2007) Fluoride interactions: from molecules to disease. Curr Signal Transduct Ther. 2:190 -213. http://dx.doi.org/10.2174/157436207781745300.

[57]Suqing B, Yanli C, Chenling F, Yuxin F, Shuting B, Weiping T and Zhongyan S (2014) Epigallocatechin gallate improves insulin signaling by decreasing toll-like receptor 4 (TLR4) activity in adipose tissues of high-fat diet rats. Mol. Nutr. Food Res. 58:677-686 http://dx.doi.org/10.1002/mnfr.201300335.

[58] Susheela AK (2007) a treatise on fluorosis: Fluorosis Research and Rural Development Foundation. 3rd Ed. New Delhi:

[59] Suttie JW, Phillips PH (1960) Fat utilization in the fluoride fed rat. J. Nutr. 1960; 72, 429-434.

[60]Thangapandiyan S, Miltonprabu S (2013) Epigallocatechin gallate effectively ameliorates fluoride induced oxidative stress, DNA damage in the liver of rats. Can. J. Physiol. Pharmacol. 2013; 91:528-537. http://dx.doi.org/10.1139/cjpp-2012-0347.

[61]Thangapandiyan S, Miltonprabu S (2014) Epigallocatechin gallate supplementation protects against renal injury induced by Fluoride intoxication in rats: Role of Nrf2/HO-1 signaling. Toxicol. Rep.1:12-30.

[62]Zhao B, Guo Q, Xin W (2001) Free radical scavenging by green tea polyphenols. Methods Enzymol. 77: 334-351.

[63]Zhong Y, Shahidi F (2011) Lipophilized epigallocatechin gallate (EGCG) derivatives as novel antioxidants. J. Agric. Food Chem. 59:6526-6533. http://dx.doi.org/10.1021/jf201050j.

[64]Zilversmit DB, Davis AK (1950) Micro determination of phospholipids by TCA precipitation. J. Lab. Clin. Med. 35:155-159.

[65]Zlatkis A, Zak B, Boyle GJ (1953) A simple method for determination of serum cholesterol. Clin. J. Med 1953; 41:486-492.

[66]Zunino SJ, Storms DH, Stephensen CB (2007) Diets rich in polyphenols and vitamin A inhibit the development of type I autoimmune diabetes in non-obese diabetic mice. J Nutr. 137:1216-21. 